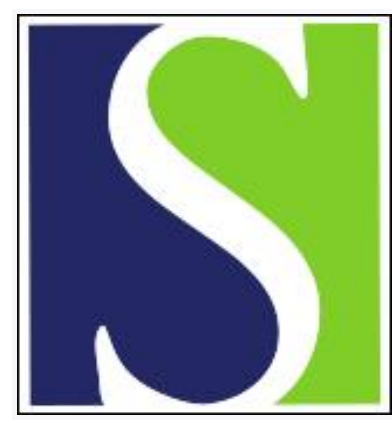

Scand J Work Environ Health 1995;21(2):96-105

https://doi.org/10.5271/sjweh.16

Issue date: Apr 1995

Fish consumption and exposure to persistent organochlorine compounds, mercury, selenium and methylamines among Swedish fishermen

by Svensson B-G, Nilsson A, Jonsson E, Schütz A, Åkesson B, Hagmar L

The following article refers to this text: 2004;30(1):30-35

Key terms: consumption; exposure; fish; fish consumption; fisherman; mercury; methylamine; PCP; persistent organochlorine compound; polychlorinated biphenyl; polychlorinated dibenzo-p-dioxin; polychlorinated dibenzofuran; selenium; Sweden

This article in PubMed: www.ncbi.nlm.nih.gov/pubmed/7618064 


\title{
Fish consumption and exposure to persistent organochlorine compounds, mercury, selenium and methylamines among Swedish fishermen
}

\author{
by Bengt-Göran Svensson, MD, ${ }^{1}$ Anita Nilsson, RN, ${ }^{1}$ Elizabeth Jonsson, ${ }^{1}$ Andrejs Schütz, PhD, ${ }^{1}$ \\ Bengt Akesson, PhD, ${ }^{1}$ Lars Hagmar, $M D^{1}$
}

\begin{abstract}
Svensson B-G, Nilsson A, Jonsson E, Schütz A, Åkesson B, Hagmar L. Fish consumption and exposure to persistent organochlorine compounds, mercury, selenium and methylamines among Swedish fishermen. Scand $J$ Work Environ Health 1995;21:96-105.
\end{abstract}

\begin{abstract}
Objectives This study assessed dietary habits and exposure to selenium, persistent organochlorine compounds, methylmercury, and methylamines among Swedish fishermen.

Methods Two hundred and fifty randomly selected subjects from a cohort of 2896 fishermen from the Swedish east coast (Baltic Sea) and 8477 fishermen from the west coast (Skagerrak and Kattegatt) were interviewed along with 250 referents. Subgroups of fishermen and referents from different coastal areas were also selected for blood and urine sampling.

Results The interview data showed that fishermen ate almost twice as much fish as the 250 referents from the general population. The blood levels of mercury were twice as high, and the plasma selenium levels were $10-$ $15 \%$ higher in the fishermen than in the referents. There was, however, no difference between the fishermen's cohorts with respect to these variables. Fishermen from the east coast ate more fatty fish than fishermen from the west coast, and they also had higher blood levels of persistent organochlorine compounds such as polychlorinated biphenyls and polychlorinated dibenzo p-dioxins and furans (present in fatty fish species in the Baltic Sea) than both the westcoast fishermen and the referents.

Conclusions A cohort of Swedish eastcoast fishermen might be a suitable study base for epidemiologic studies on the mortality and cancer morbidity associated with dietary exposure to persistent organochlorine compounds.
\end{abstract}

Key terms fish consumption, polychlorinated biphenyls, polychlorinated dibenzo p-dioxins and furans.

Fish is an important food supplying essential trace elements and certain vitamins. The polyunsaturated $\mathrm{n}-3$ fatty acids in fatty fish species are biologically important and have been associated with a decreased risk for cardiovascular diseases (1). In addition, fish contain fairly high levels of selenium (2), species of marine origin more than fresh-water fish, and they are considered an important source of selenium for the Swedish population (3). A low selenium intake, or low levels of selenium in blood, have been associated with increased risks for cancer (4) and ischemic heart disease $(5,6,7)$.

However, fish can be contaminated with environmental pollutants, some of them having great toxic potential. Carcinogenic persistent organochlorine compounds such as polychlorinated biphenyls (PCB) (8), polychlorinated dibenzo-p-dioxins (PCDD), and polychlorinated dibenzofurans (PCDF) (9) are widely spread throughout the general environment. The levels of PCB in herring caught in the Baltic Sea are two to three times higher than the corresponding levels in herring from the west coast of Sweden (10). In a recent study we found that the consumption of fatty fish from the Baltic Sea is an important source of exposure to different PCB congeners (11).

During the last decade, PCDD/PCDF have been found at surprisingly high levels in fatty fish such as herring and salmon from the Baltic Sea (12). In addition, for these substances, the levels in herring were two to three times higher in the Baltic Sea than in the Skagerrak, west of Sweden (10). We have also found a substantial impact on the blood levels of PCDD/PCDF from the consumption of fatty fish from the Baltic Sea (13).

Consumption of fish also causes exposure to methylamines. Under certain conditions dimethylamine (DMA) might form nitrosodimethylamine (NMDA), which is a potent carcinogen in a wide variety of animal species $(14,15)$.

1 Department of Occupational and Environmental Medicine, University Hospital, Lund, Sweden.

Reprint requests to: Dr B-G Svensson, Department of Occupational and Environmental Medicine, University Hospital, S-221 85 Lund, Sweden. 
Consumption of fish is also an important source of exposure to methylmercury in humans $(16,17)$. Fish from some coastal areas of the Baltic Sea contain higher levels of methylmercury than fish from Kategatt, Skagerrak, and the North Sea (18). Chromosome aberrations in humans have been reported after methylmercury exposure through fish consumption (19), but the epidemiologic data on human cancer risk from this exposure is still limited (20).

Swedish fishermen living in the southern part of the Swedish east coast had a higher consumption of fish than the average population in the same county (21). It is thus reasonable to use Swedish eastcoast fishermen as a study base for assessments of cancer incidence and mortality patterns associated with a high consumption of fatty fish from the Baltic Sea.

The objective of the present study was to assess the dietary habits and exposure to selenium, persistent organochlorine compounds, methylmercury, and methylamines among fishermen along the Swedish east and west coasts and among referents from the general population in the same regions. The cancer incidence and cause-specific mortality in Swedish east- and westcoast fishermen have been presented in a separate article (22).

\section{Materials and methods}

\section{Study base and dietary interviews}

One hundred and fifty fishermen from the east coast and 100 from the west coast were interviewed over the telephone about their food frequencies for 27 different food items, as well as for their coffee, tobacco, and alcohol consumption. Moreover, color pictures of three different sizes of fish portions of four fish species were distributed to the interviewed subjects beforehand, together with the questionnaire. They were asked which size most resembled their usual fish portion of cod $(115,190$, or $300 \mathrm{~g})$, herring $(135,225$, or $360 \mathrm{~g})$, salmon $(135,225$, or $360 \mathrm{~g})$, or flatfish $(280,545$, or $865 \mathrm{~g})$. The average weekly consumption was then calculated from the frequencies and portion sizes indicated. One hundred and fifty eastcoast and 98 westcoast referents, matched with respect to gender, age, and county of residence, were randomly selected from the population register and interviewed in the same way.

The fishermen were randomly selected from those still alive in cohorts of 8477 fishermen from the west coast of Sweden, and 2896 fishermen from the east coast of Sweden. These cohorts have been described in detail elsewhere (22). Altogether 125 new selections had, however, to be made due to dropouts, 69 subjects refused to participate, 15 subjects were too old or too sick to be able to participate, and the remaining 41 could not be inter- viewed due to various reasons. Altogether 132 new referents had to be chosen, mainly due to the same reasons as for the fishermen.

\section{Blood and urine sampling}

Subgroups of fishermen and referents from different coastal areas were selected for blood and urine sampling (table 1 and figure 1). The subgroups from the west coast and Baltic south were selected from the aforementioned interviewed subjects. The subsamples of fishermen from the Baltic proper and the Sea of Bothnia were, due to

Table 1. Subsamples of cohorts of Swedish fishermen from different coastal areas subjected to blood sampling.

\begin{tabular}{|c|c|c|c|c|c|c|}
\hline \multirow[t]{3}{*}{ Coastal area } & \multicolumn{3}{|c|}{ Fishermen } & \multicolumn{3}{|c|}{ Referents } \\
\hline & \multirow[t]{2}{*}{ Number } & \multicolumn{2}{|c|}{ Age (years) } & \multirow[t]{2}{*}{ Number } & \multicolumn{2}{|c|}{ Age (years) } \\
\hline & & Mean & SD & & Mean & SD \\
\hline West coasta & 29 & 53.2 & 14.4 & 29 & 52.0 & 14.6 \\
\hline \multicolumn{7}{|l|}{ East coast } \\
\hline Baltic southa & 27 & 59.8 & 15.6 & 29 & 57.3 & 16.4 \\
\hline Baltic propert & 28 & 51.2 & 12.2 & 29 & 48.4 & 9.6 \\
\hline Sea of Bothniab & 29 & 54.9 & 10.7 & 32 & 48.7 & 9.2 \\
\hline
\end{tabular}

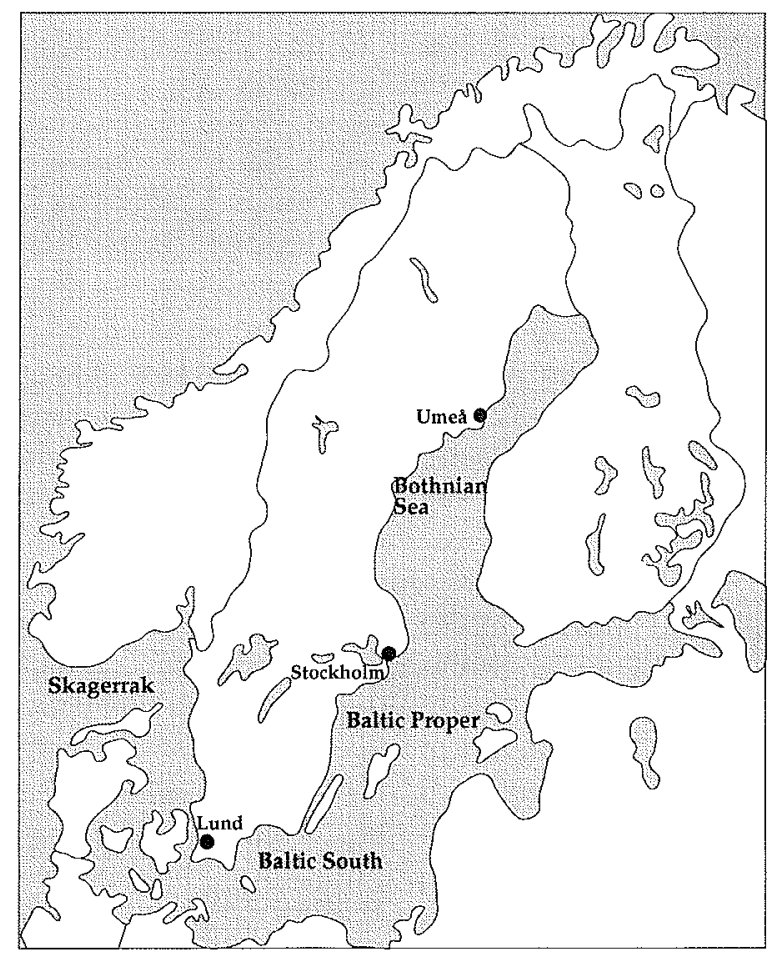

Figure 1. Coastal areas in Sweden where the blood and urine samples were collected from the fishermen and referents. 
practical reasons, nonrandomly selected from the cohort members according to place of residence. As referents to these nonrandomly selected fishermen, subjects were recruited from major workplaces in the areas. The referents were a mix of blue- and white-collar workers not occupationally exposed to chlorine compounds or mercury. At the time of the blood sampling, these subjects were interviewed about their dietary habits with the technique already described. The age distributions in the subgroups of fishermen were similar to that of subjects still alive in the total cohorts.

Blood was collected in metal-free evacuated tubes (Venoject $^{\circledR}$ ) from a cubital vein with heparin as an anticoagulant. Whole blood was used for the mercury analysis. For the assays of lipoprotein (a), selenium, and polychlorinated organic compounds, the samples were centrifuged at $2000 \mathrm{~g}$ for $10 \mathrm{~min}$, and the supernatant was drawn off for further analyses. Plasma for analyses of persistent organochlorine compounds was stored in acetone-washed glass bottles at $-20^{\circ} \mathrm{C}$.

Overnight urine was collected in acid-washed bottles. Aliquots of $25 \mathrm{ml}$ of urine were acidified with $5 \mathrm{ml}$ of $5 \mathrm{M}$ acetic acid and kept at $-20^{\circ} \mathrm{C}$ until the analysis.

\section{Lipoprotein (a) in plasma}

In samples from each subject, lipoprotein (a) was determined with the routine immunochemical method used at the Department of Clinical Chemistry, University Hospital, Lund. Levels above 300 units $\cdot 1^{-1}$ (discrimination level) have been shown to be associated with an increased risk for cardiovascular diseases (23).

\section{Mercury in blood}

Mercury was determined in wet-digested samples using an automized cold vapor atomic absorption technique (24). For the determination of total mercury, blood $(0.5 \mathrm{~g})$ was digested with concentrated nitric $(0.5 \mathrm{ml})$ and perchloric $(2.5 \mathrm{ml})$ acids at $65^{\circ} \mathrm{C}$ overnight (25). Inorganic mercury was determined after digestion with sulfuric acid $(3.0 \mathrm{ml}, 16 \mathrm{M})(26)$. All of the samples were analyzed in duplicate.

The detection limit was $0.15 \mathrm{pmol}(30 \mathrm{pg})$ per sample. The precision for the total mercury determinations, calculated as the coefficient of variation $(\mathrm{CV})$ for the duplicate analysis, was $5 \%$ below 15 (mean 9.7) nmol . $\mathrm{l}^{-1}$, and $3 \%$ in the range $15-76$ (mean 30 ) $\mathrm{nmol} \cdot \mathrm{1}^{-1}$. For inorganic mercury, the coefficient of variation was $9 \%$ below 3 (mean 1.5 ) nmol $\cdot \mathrm{I}^{-1}$, and $4 \%$ in the range 3-24 (mean 5.5) nmol $\cdot 1^{-1}$.

In an earlier study, the calculated difference between the total and inorganic mercury levels in whole blood, as determined by the methods used, showed a good correlation with the methylmercury levels determined by gas- chromatography mass spectrometry (26). Thus what is referred to later on as methylmercury denotes the difference between total and inorganic mercury in whole blood.

\section{Selenium in plasma}

Selenium was determined fluorometrically (27). The detection limit was $0.04 \mu \mathrm{mol} \cdot \mathrm{l}^{-1}\left(3 \mu \mathrm{g} \cdot \mathrm{l}^{-1}\right)$. All of the samples were analyzed in duplicate, and the coefficient of variation was 5\%. Our average for a serum reference sample (Seronorm ${ }^{\circledR}$ trace elements, batch 112 , Nycomed AS, Oslo) was 1.05 (SD 0.04) $\mu \mathrm{mol} \cdot 1^{-1}$ $(\mathrm{N}=18)$, as compared with the recommended $1.1 \mu \mathrm{mol}$. $\mathrm{I}^{-1}\left(90 \mu \mathrm{g} \cdot \mathrm{I}^{-1}\right)$.

\section{Amines in urine}

The dimethylamine (DMA), trimethylamine (TMA), and trimethylamine- $N$-oxide (TMAO) concentrations in urine were determined with gas-liquid chromatography (GLC) as described elsewhere (28). Creatinine in urine was determined with a modified kinetic Jaffé method (29).

\section{Polychlorinated biphenyls, polychlorinated dibenzo p-dioxins and furans}

From each of the stored glass bottles of plasma about $8 \mathrm{ml}$ of plasma was drawn and pooled in new, acetonewashed Teflon ${ }^{\circledR}$ bottles in eight area pools according to table 1 . These pooled samples were coded and sent for analysis to the Midwest Research Institute, Kansas City, Missouri, United States, where congener specific PCDD, PCDF and PCB were determined with high-resolution mass spectrometry (PCDD, PCDF, and coplanar PCB), and high-resolution gas chromatography with an electron capture detector (the major specific PCB isomers and total PCB). The analytical procedures were evaluated in a quality-control study organized by the World Health Organization, and the laboratory was considered qualified to analyze PCDD/PCDF and PCB (30).

Relative toxic potencies of the different $\mathrm{PCB}$ congeners, as compared with TCDD, expressed as toxic equivalents (TEQ), have been calculated according to the WHO interim model (31). For the different PCDD/ PCDF, TCDD equivalents according to a Nordic Expert Group were used (32).

\section{Statistical methods}

The Mann-Whitney U-test was used for evaluating the group differences in blood levels of mercury and selenium and in dietary habits and alcohol and tobacco consumption. Chi-squared tests were used for investigating group differences in lipoprotein (a). Associations were 
investigated by correlation coefficients (Pearson's r). The term "significant" refers to $\mathrm{P} \pm 0.05$.

\section{Results}

Fish consumption

The intake of fish, expressed both as numbers of fish meals per week and as average weekly consumption of different fish species, was higher among the fishermen from the east coast than among their corresponding referents (tables 2 and 3). The eastcoast fishermen had a higher intake of both fatty and lean fish species than the referents (table 2).

The fishermen from the west coast also had fish meals, both of fatty and lean species, more often than their referents (table 2). However, considering the fatty fish species salmon and herring, there were no differences between westcoast fishermen and the referents in the estimated average amount consumed of these species (table 3).

There were no differences in the total numbers of fish meals per week between the east- and westcoast fishermen (table 2). The two groups differed however as regards fish species consumed. The estimated average

Table 2. Food frequencies, alcohol consumption, and smoking habits of 150 fishermen from the east coast and 100 fishermen from the west coast, randomly selected from the cohorts, and 248 referents from the regional reference population, matched by age and gender.

\begin{tabular}{|c|c|c|c|c|c|c|c|c|c|c|c|}
\hline & \multicolumn{5}{|c|}{ Fishermen } & \multicolumn{6}{|c|}{ Referents } \\
\hline & \multicolumn{2}{|c|}{$\begin{array}{l}\text { East coast } \\
(\mathbb{N}=150)\end{array}$} & \multicolumn{2}{|c|}{$\begin{array}{l}\text { West coast } \\
(N=100)\end{array}$} & \multirow[t]{2}{*}{ P-value ${ }^{a}$} & \multicolumn{2}{|c|}{$\begin{array}{l}\text { East coast } \\
\langle N=150\rangle\end{array}$} & \multirow[t]{2}{*}{ P-value ${ }^{b}$} & \multicolumn{2}{|c|}{$\begin{array}{l}\text { West coast } \\
(\mathrm{N}:=98)\end{array}$} & \multirow[t]{2}{*}{ P-value } \\
\hline & Mean & SD & Mean & SD & & Mean & SD & & Mean & $\mathrm{SD}$ & \\
\hline Fish ${ }^{\circ}$ & 2.6 & 1.6 & 2.8 & 1.5 & 0.29 & 1.6 & 1.0 & $<0.0001$ & 1.5 & 1.1 & $<0.0001$ \\
\hline $\begin{array}{l}\text { Lean fish } \\
\text { Fatty fish } \\
\text { Smoked fish }\end{array}$ & $\begin{array}{l}1.2 \\
1.4 \\
0.8\end{array}$ & $\begin{array}{l}0.9 \\
1.3 \\
1.2\end{array}$ & $\begin{array}{l}1.9 \\
0.9 \\
0.4\end{array}$ & $\begin{array}{l}1.0 \\
0.9 \\
0.8\end{array}$ & $\begin{array}{c}<0.0001 \\
0.0002 \\
0.008\end{array}$ & $\begin{array}{l}0.8 \\
0.8 \\
0.3\end{array}$ & $\begin{array}{l}0.6 \\
0.8 \\
0.6\end{array}$ & $\begin{array}{r}0.0003 \\
<0.0001 \\
<0.0001\end{array}$ & $\begin{array}{l}1.0 \\
0.5 \\
0.2\end{array}$ & $\begin{array}{l}0.7 \\
0.6 \\
0.6\end{array}$ & $\begin{array}{c}<0.0001 \\
<0.0001 \\
0.04\end{array}$ \\
\hline Meat $^{c}$ & 2.6 & 1.4 & 2.9 & 1.3 & 0.27 & 2.5 & 1.3 & $>0.5$ & 3.0 & 1.6 & $>0.5$ \\
\hline Bacon, sausages & 1.6 & 1.4 & 1.7 & 1.4 & $>0.5$ & 1.8 & 1.1 & 0.005 & 1.8 & 1.4 & 0.33 \\
\hline Fresh vegetables ${ }^{d}$ & 5.5 & 4.9 & 5.2 & 4.1 & $>0.5$ & 5.9 & 4.1 & 0.09 & 7.1 & 5.0 & 0.008 \\
\hline Potatoes ${ }^{\mathrm{C}}$ & 6.4 & 2.2 & 6.2 & 1.6 & $>0.5$ & 5.3 & 1.9 & 0.0001 & 5.6 & 2.4 & 0.001 \\
\hline Fresh fruits ${ }^{d}$ & 6.2 & 5.7 & 7.3 & 5.5 & 0.04 & 6.3 & 4.6 & 0.32 & 7.5 & 5.4 & $>0.5$ \\
\hline Coffee $^{e}$ & 5.6 & 3.7 & 5.4 & 3.6 & $>0.5$ & 4.2 & 2.5 & 0.001 & 4.1 & 2.7 & 0.004 \\
\hline Alcoholf & 390 & 470 & 330 & 390 & 0.30 & 360 & 380 & $>0.5$ & 410 & 380 & 0.02 \\
\hline Smoking habits & 15.7 & 22.1 & 12.5 & 17.2 & 0.09 & 11.4 & 17.3 & 0.03 & 12.2 & 16.8 & $>0.5$ \\
\hline
\end{tabular}

a Comparison between the east- and westcoast fishermen.

b Comparison between the fishermen and the referents.

- Meals per week.

d Weekly.

e Cups per day.

1 Grams of alcohol per month

g Pack-years ( 1 pack-year $=20$ cigarettes a day for one year or, eg, 10 cigarettes a day for two years)

Table 3. Estimated average consumption (grams per week) of four species of fish for 150 fishermen from the east coast, 100 fishermen from the west coast, and 248 referents, matched for age, gender and county.

\begin{tabular}{|c|c|c|c|c|c|c|c|c|c|c|c|}
\hline & \multicolumn{5}{|c|}{ Fishermen } & \multicolumn{6}{|c|}{ Referents } \\
\hline & \multicolumn{2}{|c|}{$\begin{array}{l}\text { East coast } \\
(N=150)\end{array}$} & \multicolumn{2}{|c|}{$\begin{array}{l}\text { West coast } \\
(N=100)\end{array}$} & \multirow[t]{2}{*}{$\mathrm{Pa}^{\mathrm{a}}$} & \multicolumn{2}{|c|}{$\begin{array}{l}\text { East coast } \\
(\mathrm{N}=150)\end{array}$} & \multirow[t]{2}{*}{$\mathrm{Pb}$} & \multicolumn{2}{|c|}{$\begin{array}{c}\text { West coast } \\
(\mathrm{N}=98)\end{array}$} & \multirow[t]{2}{*}{$\mathrm{pb}$} \\
\hline & Mean & $\mathrm{SD}$ & Mean & $S D$ & & Mean & SD & & Mean & $\mathrm{SD}$ & \\
\hline Cod filet & 161 & 145 & 270 & 214 & $<0.0001$ & 97 & 99 & $<0.0001$ & 128 & 138 & $<0.0001$ \\
\hline Flat fish & 218 & 282 & 487 & 403 & $<0.0001$ & 99 & 148 & 0.0003 & 161 & 203 & $<0.0001$ \\
\hline Salmon & 119 & 159 & 37 & 108 & $<0.0001$ & 54 & 90 & $<0.0001$ & 31 & 52 & 0.24 \\
\hline Herring & 208 & 253 & 73 & 107 & $<0.0001$ & 103 & 121 & 0.0001 & 59 & 119 & 0.24 \\
\hline
\end{tabular}

a Comparison between the east- and westcoast fishermen

b Comparison between the fishermen and the referents. 
weekly intake, for eastcoast fishermen, of the fatty fish species salmon and herring were about three times higher than for westcoast fishermen $(\mathrm{P}<0.0001$, table 3$)$, who in turn had a higher consumption of lean fish species such as cod $(\mathrm{P}<0.0001)$ and flat fish $(\mathrm{P}<0.0001)$.

The referents from the east coast had, as a mean, $60 \%$ more fatty fish meals per week than the referents from the west coast $(P=0.008)$. There were, however, no differences between the reference groups as regards total number of weekly fish meals (table 2).

Among the interviewed eastcoast fishermen 28\% had decreased and $15 \%$ had increased their fish consumption during the last $10-20$ years, as compared with 28 and $29 \%$, respectively, among the referents $(\mathrm{P}=0.05)$. The corresponding proportions among the westcoast fishermen and their referents were 47 and $14 \%$, and 22 and $26 \%$, respectively $(\mathrm{P}=0.0001)$.

There was no difference in the total intake of fish of fishermen who were selected randomly and nonrandomly from the east coast, subjected to blood and urine sampling. However, considering fatty fish species, those nonrandomly selected had slightly more meals per week than those randomly selected (1.9 versus $1.4 ; \mathrm{P}=0.01$ ).

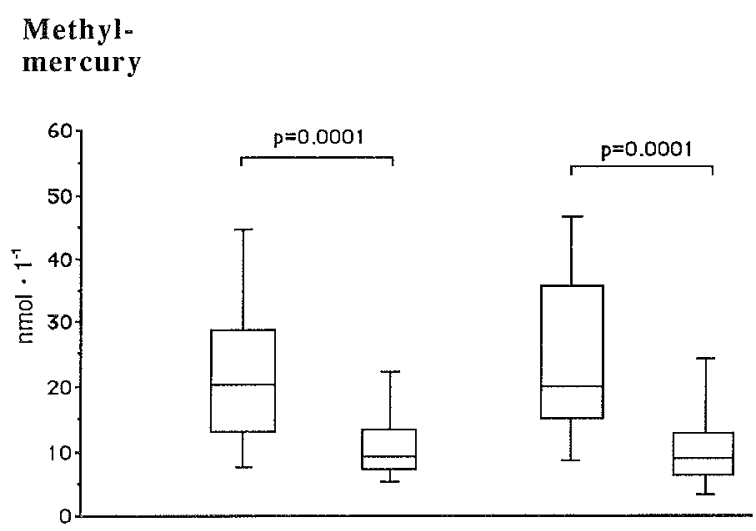

\section{Selenium}

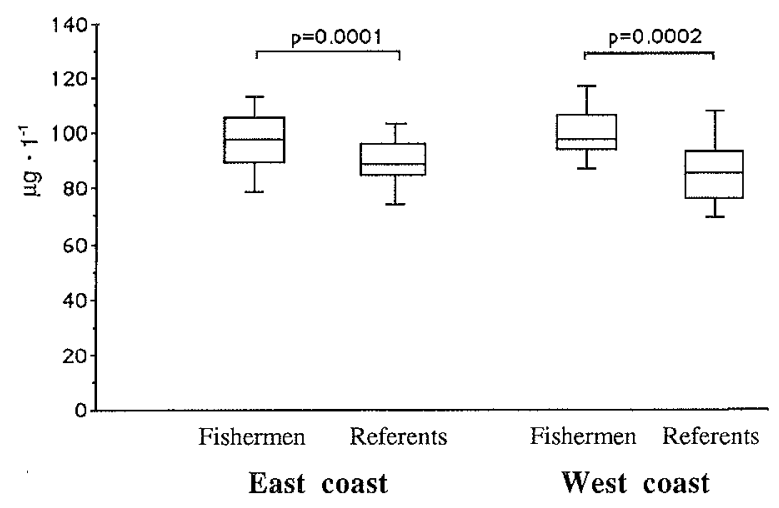

Figure 2. Levels of methylmercury in blood and selenium in plasma in samples from fishermen and referents from different Swedish coastal areas $(10,25,50,75$ and 90 percentiles indicated).
The difference in estimated amounts of fatty fish consumed was even less impressive, $383 \mathrm{~g}$ a week versus $327 \mathrm{~g}$ a week $(\mathrm{P}=0.07)$.

\section{Other dietary habits and coffee, alcohol and tobacco} consumption

The eastcoast fishermen consumed more potatoes and coffee than the eastern referents (table 2). The lifetime cigarette consumption was increased by about $40 \%$ among the eastcoast fishermen, as compared with their referents.

In addition, the westcoast fishermen drank more coffee and ate more potatoes than their referents. The referents, on the other hand, ate fresh vegetables more often than the fishermen, and they also drank more alcohol. The smoking habits were similar.

The eastcoast fishermen consumed less fresh fruit than the westcoast fishermen $(P=0.04)$. Otherwise there were no differences in food frequencies between the two groups of fishermen. The referents from the west coast had a higher intake of meat $(\mathrm{P}=0.03)$ and fresh vegetables $(\mathrm{P}=0.04)$ than the referents from the east coast (table 2).

\section{Lipoprotein (a) in plasma}

In both groups of fishermen equal proportions of the members (27\%) had plasma lipoprotein (a) levels above 300 units $\cdot 1^{-1}$. There were no statistically significant differences between the fishermen and the reference groups in numbers of subjects with lipoprotein (a) levels above this discrimination level.

\section{Selenium}

The fishermen had $10-15 \%$ higher plasma selenium levels than their referents $(\mathrm{P}=0.0001$ and 0.0002 , respectively; 8 fishermen and 11 referents on selenium tablets were excluded from the comparison) (figure 2). There were no differences in plasma selenium between the east- and westcoast fishermen or between the two reference groups. In a joint analysis of all fishermen and referents, plasma selenium correlated positively with the total intake of fish $(r=0.26 ; P=0.0001)$.

\section{Methylmercury}

The blood levels of methylmercury were twice as high among the fishermen from both the east- and the westcoast as among their corresponding referents $(P=0.0001$ and $P=0.0001$, respectively) (figure 2 ). There were no significant differences in the methylmercury levels, either between east- and westcoast fishermen or between the reference groups. The methylmercury levels correlat- 
ed with the estimated total intake of fish $(r=0.52$ $\mathrm{P}=0.0001$ ) in the joint group of fishermen and referents.

\section{Methylamines}

There were no significant differences in the urinary concentrations of DMA $(\mathrm{P}=0.21)$, TMA $(\mathrm{P}=0.11)$, or TMAO ( $P=0.08)$ between the eastcoast fishermen and the eastcoast referents (figure 3 ). The fishermen from the west coast, however, had a median level of TMA that was twice as high as that of their referents $(P=0.0001)$, and also median levels of TMAO and DMA that were 40 and $20 \%$ higher, respectively, than those of the referents $(\mathrm{P}=0.02$ and $\mathrm{P}=0.01$, respectively). Furthermore, the fishermen from the west coast had almost twice the excretion of TMA in urine ( $\mathrm{P}=0.0001)$ as compared with the eastcoast fishermen (figure 3). For DMA and TMAO there were no significant differences between the two groups of fishermen $(\mathrm{P}=0.07$ and $\mathrm{P}=0.12$, respectively).

\section{Polychlorinated biphenyls, polychlorinated dibenzo p-dioxins and furans}

Plasma levels of PCDD/PCDF congeners with high toxicity (eg, 2,3,7,8-tetrachlorodibenzo-p-dioxin and $2,3,4,7,8$-pentachlorodibenzo-furan) were two to six times higher in the three pooled plasma samples from the eastcoast fishermen than in the pooled sample from the westcoast fishermen (table 4). The levels of these congeners in the pooled sample from the westcoast fishermen were equal to the ones in the pooled sample from the westcoast referents. All three samples from the eastcoast fishermen had higher (doubled or more) PCDD/PCDF levels than the corresponding reference samples.

The eastcoast fishermen also had higher levels of non-ortho PCB (at the most two to threefold) than the westcoast fishermen (table 5). The plasma levels of the non-ortho PCB were in the same magnitude for the westcoast fishermen and the four reference groups. Furthermore, levels of other PCB were higher among the eastcoast fishermen than among those from the west coast (table 5). The sum of the PCDD/PCDF and the PCB, expressed as the TEQ, were about two times higher in the samples from the eastcoast fishermen than in that from the westcoast fishermen (table 6). The eastern fishermen had about a two times higher total TEQ than their local referents, but the total TEQ for the western fishermen was of the same magnitude as that for their local referents.

\section{Discussion}

The dietary interviews showed that fishermen from both groups had significantly higher fish consumption than

\section{DMA}

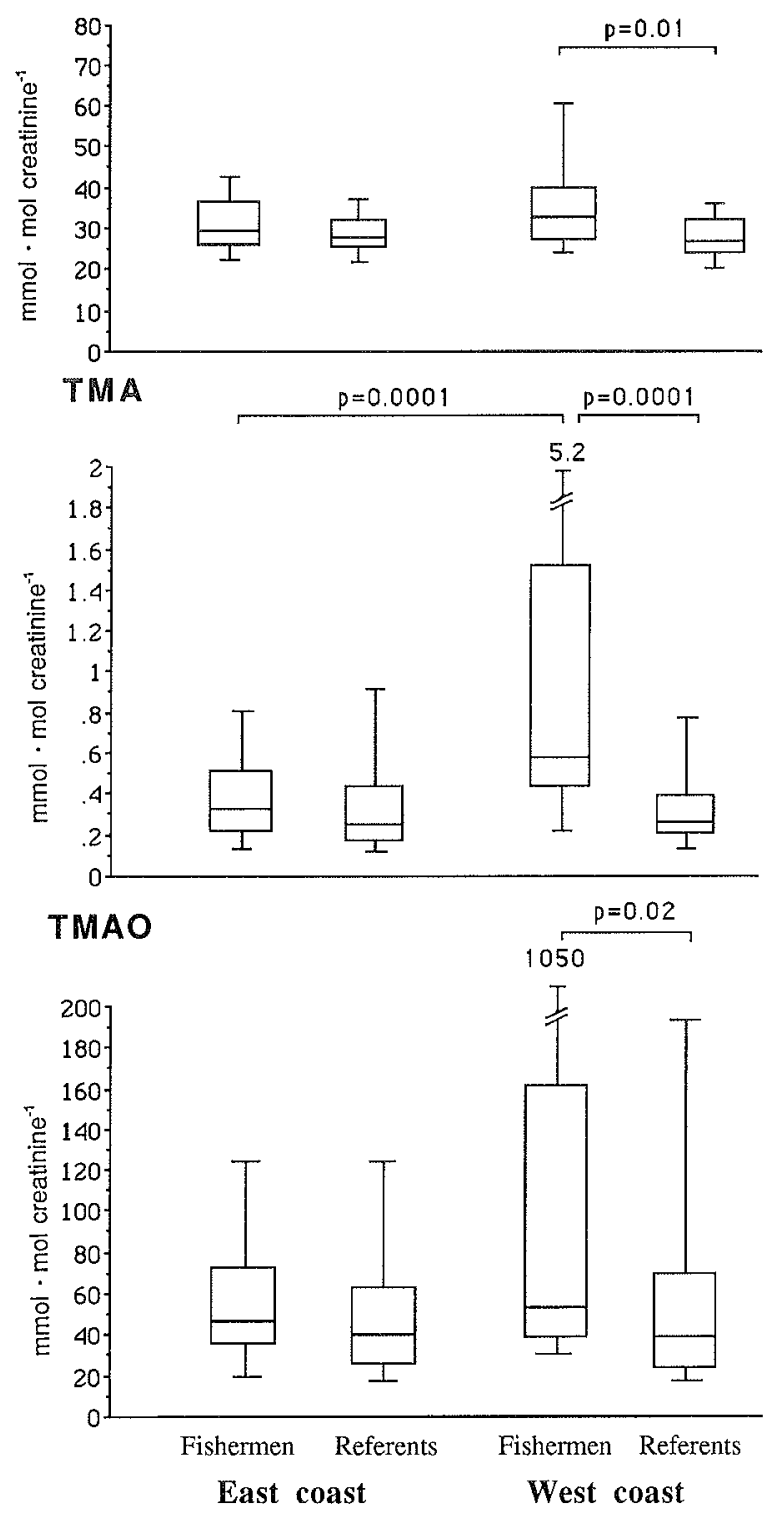

Figure 3. Urinary concentrations of dimethylamine (DMA), trimethylamine (TMA), and trimethylamine-N-oxide (TMAO) in samples from fishermen and referents from different Swedish coastal areas $(10,25$, 50,75 and 90 percentiles indicated).

their referents. This finding was reflected by the higher levels of selenium and methylmercury among the fishermen. Fishermen from the east coast had a higher intake of fatty fish than the fishermen from the west coast, who in turn had a higher intake of lean fish. This finding was in accordance with the fact that the blood levels of highly fat-soluble persistent organochlorine compounds (PCDD/ PCDF and PCB) were higher in the eastcoast fishermen than in the fishermen from the west coast.

The plasma selenium levels were in accordance with those previously reported from Sweden $(33,34,35$, and 
Table 4. Lipid-related plasma levels (pg $\mathrm{g}$ lipid $^{-1}$ ) of PCDD/F, with chlorine in the $2,3,7,8$ positions, in eight pooled blood samples from fishermen and referents living in different coastal areas in Sweden. (TCDD = tetrachlorodibenzo-p-dioxin, PeCDD = pentachlorodibenzodioxin, HxCDD = hexachlorodibenzodioxin, HpCdd = heptachlorodibenzodioxin, OCDD = octachlorodibenzodioxin, $T C D F=$ tetrachlorodibenzofuran, $\mathrm{PeCDF}=$ pentachlorodibenzofuran, $\mathrm{HxCDF}=$ hexachlorodibenzofuran, $\mathrm{HpCDF}=$ heptachlorodibenzofuran, OCDF = octachlorodibenzofuran, $\mathrm{ND}=$ below the detection limit)

\begin{tabular}{|c|c|c|c|c|c|c|c|c|}
\hline \multirow[t]{2}{*}{ Compound } & \multicolumn{2}{|c|}{ Sea of Bothnia } & \multicolumn{2}{|c|}{ Baltic Proper } & \multicolumn{2}{|c|}{ Baltic South } & \multicolumn{2}{|c|}{ West coast } \\
\hline & $\begin{array}{l}\text { Fisher- } \\
\text { men }\end{array}$ & Referents & $\begin{array}{c}\text { Fisher- } \\
\text { men }\end{array}$ & Referents & $\begin{array}{c}\text { Fisher- } \\
\text { men }\end{array}$ & Referents & $\begin{array}{l}\text { Fisher- } \\
\text { men }\end{array}$ & Referents \\
\hline $2,3,7,8 \mathrm{TCDD}$ & 27 & 6.1 & 6.9 & 4.0 & 17 & 6.4 & 5.7 & 4.0 \\
\hline $1,2,3,7,8 \mathrm{PeCDD}$ & 35 & 12 & 20 & 10 & 33 & 14 & 11 & 13 \\
\hline $1,2,3,4,7,8 \mathrm{HxCDD}$ & 6.2 & 4.2 & 4.6 & 3.4 & 8.8 & 5.8 & 4.9 & ND \\
\hline $1,2,3,6,7,8 \mathrm{H} \times C D D$ & 66 & 38 & 44 & 32 & 75 & 53 & 36 & 34 \\
\hline $1,2,3,7,8,9 \mathrm{H} \times \mathrm{CDD}$ & 12 & 6.6 & ND & 5.7 & ND & 8.5 & 6.0 & ND \\
\hline $1,2,3,4,6,7,8 \mathrm{HpCDD}$ & 84 & 67 & 58 & 58 & 110 & 100 & 54 & 85 \\
\hline OCDD & 551 & 574 & 351 & 364 & 585 & 605 & 367 & 553 \\
\hline $2,3,7,8 \mathrm{TCDF}$ & 4.8 & ND & ND & ND & 4.8 & 2.6 & ND & ND \\
\hline $1,2,3,7,8 \mathrm{PeCDF}$ & ND & ND & ND & ND & ND & ND & ND & ND \\
\hline $2,3,4,7,8 \mathrm{PeCDF}$ & 198 & 40 & 110 & 41 & 163 & 59 & 47 & 42 \\
\hline $1,2,3,4,7,8 \mathrm{H} \times C D F$ & ND & 5.9 & 9.7 & 7.0 & 19 & 10 & 8.0 & 8.9 \\
\hline $1,2,3,6,7,8 \mathrm{HxCDF}$ & ND & 6.8 & 12 & 7.0 & 23 & 10 & 8.0 & 9.6 \\
\hline $2,3,4,6,7,8 \mathrm{H} \times \mathrm{CDF}$ & 5.0 & ND & 4.0 & 2.6 & 7.3 & ND & 3.0 & 4.8 \\
\hline $1,2,3,7,8,9 \mathrm{H} \times \mathrm{CDF}$ & ND & ND & ND & ND & ND & ND & ND & ND \\
\hline $1,2,3,4,6,7,8 \mathrm{HpCDF}$ & 16 & 19 & 16 & 15 & 31 & 20 & 14 & 18 \\
\hline $1,2,3,4,7,8,9 \mathrm{HpCDF}$ & ND & ND & ND & 0.8 & ND & ND & ND & ND \\
\hline OCDF & ND & ND & ND & 3.2 & ND & 6.8 & 2.9 & 3.2 \\
\hline
\end{tabular}

Table 5. Lipid-related plasma levels of different PCB (polychlorinated biphenyl) congeners in eight pooled blood samples from fishermen and referents living in different coastal areas in Sweden. (ND = below detection limit)

\begin{tabular}{|c|c|c|c|c|c|c|c|c|}
\hline \multirow[t]{2}{*}{$\mathrm{PCB}^{\mathrm{a}, \mathrm{b}}$} & \multicolumn{2}{|c|}{ Sea of Bothnia } & \multicolumn{2}{|c|}{ Baltic Proper } & \multicolumn{2}{|c|}{ Baltic South } & \multicolumn{2}{|c|}{ West coast } \\
\hline & $\begin{array}{c}\text { Fisher- } \\
\text { men }\end{array}$ & Referents & $\begin{array}{c}\text { Fisher- } \\
\text { men }\end{array}$ & Referents & $\begin{array}{c}\text { Fisher- } \\
\text { men }\end{array}$ & Referents & $\begin{array}{c}\text { Fisher- } \\
\text { men }\end{array}$ & Referents \\
\hline \multicolumn{9}{|c|}{ Non-ortho PCB $\left(\mathrm{pg} \cdot \mathrm{g}^{-1}\right)$} \\
\hline $\begin{array}{l}77 \\
126 \\
169\end{array}$ & $\begin{array}{l}216 \\
612 \\
555\end{array}$ & $\begin{array}{l}236 \\
256 \\
183\end{array}$ & $\begin{array}{l}165 \\
560 \\
608\end{array}$ & $\begin{array}{l}111 \\
329 \\
216\end{array}$ & $\begin{array}{r}206 \\
1050 \\
907\end{array}$ & $\begin{array}{r}79 \\
437 \\
308\end{array}$ & $\begin{array}{l}153 \\
368 \\
292\end{array}$ & $\begin{array}{l}151 \\
282 \\
180\end{array}$ \\
\hline \multicolumn{9}{|c|}{ Mono-ortho PCB $\left(\mathrm{ng} \cdot \mathrm{g}^{-1}\right)$} \\
\hline $\begin{array}{l}105 \\
118 \\
156\end{array}$ & $\begin{array}{r}32 \\
120 \\
76\end{array}$ & $\begin{array}{l}10 \\
36 \\
37\end{array}$ & $\begin{array}{l}22 \\
82 \\
68\end{array}$ & $\begin{array}{l}14 \\
52 \\
39\end{array}$ & $\begin{array}{r}40 \\
167 \\
108\end{array}$ & $\begin{array}{l}18 \\
77 \\
59\end{array}$ & $\begin{array}{l}16 \\
65 \\
59\end{array}$ & $\begin{array}{l}10 \\
61 \\
41\end{array}$ \\
\hline \multicolumn{9}{|c|}{ Di-ortho PCB $\left(n g \cdot g^{-1}\right)$} \\
\hline $\begin{array}{l}128 \\
138 \\
153 \\
170 \\
180\end{array}$ & $\begin{array}{r}60 \\
307 \\
541 \\
246 \\
476\end{array}$ & $\begin{array}{r}16 \\
114 \\
216 \\
126 \\
200\end{array}$ & $\begin{array}{r}36 \\
216 \\
415 \\
209 \\
396\end{array}$ & $\begin{array}{r}17 \\
117 \\
226 \\
125 \\
220\end{array}$ & $\begin{array}{r}76 \\
442 \\
836 \\
306 \\
661\end{array}$ & $\begin{array}{r}29 \\
88 \\
345 \\
172 \\
347\end{array}$ & $\begin{array}{r}27 \\
186 \\
336 \\
165 \\
290\end{array}$ & $\begin{array}{r}17 \\
123 \\
234 \\
127 \\
212\end{array}$ \\
\hline \multicolumn{9}{|c|}{ Other PCB $\left(n g \cdot g^{-1}\right)$} \\
\hline $\begin{array}{l}74 \\
99 \\
101 \\
183 \\
187\end{array}$ & $\begin{array}{r}34 \\
60 \\
60 \\
57 \\
129\end{array}$ & $\begin{array}{l}13 \\
18 \\
52 \\
21 \\
50\end{array}$ & $\begin{array}{r}29 \\
41 \\
35 \\
40 \\
107\end{array}$ & $\begin{array}{l}30 \\
28 \\
31 \\
22 \\
55\end{array}$ & $\begin{array}{r}52 \\
71 \\
23 \\
82 \\
202\end{array}$ & $\begin{array}{l}38 \\
33 \\
21 \\
34 \\
76\end{array}$ & $\begin{array}{l}25 \\
31 \\
25 \\
30 \\
80\end{array}$ & $\begin{array}{l}21 \\
21 \\
18 \\
22 \\
50\end{array}$ \\
\hline Total $\left(n g \cdot g^{-1}\right)$ & 2200 & 908 & 1696 & 976 & 3067 & 1337 & 1336 & 956 \\
\hline
\end{tabular}

a The non-, mono- and di-ortho congeners indicated are also chlorinated in both para and at least two meta positions.

b By IUPAC number (IUPAC = International Union of Pure and Applied Chemistry).

Schïtz et al, unpublished report). An association between plasma selenium and fish intake has also been found in other studies $(17,35,36$, and Schütz et al, unpublished report). The impact on plasma selenium levels from fish consumption is, however, limited, with a $10-15 \%$ difference between fishermen and referents. A similar effect was seen in a "fish-feeding" study (37), where intake of $150-200 \mathrm{~g}$ of fish per day for 11 weeks resulted in a $13 \%$ rise in plasma selenium.

The chemical form of selenium in fish is virtually unknown (2). Furthermore, information on the absorption of selenium from fish and its bioavailablity is either 
Table 6. Total plasma levels of polychlorinated dibenzo-p-dioxins/polychlorinated dibenzofurans (PCDD/PCDF) and polychlorinated biphenyls (PCB), expressed as the Nordic toxic equivalents (TEQ) for PCDD/PCDF and as WHO interim TEQ for PCBs $\left(\mathrm{pg} \cdot \mathrm{g} \mathrm{lipid}^{-1}\right)$ in eight pooled blood samples from fishermen and referents living in different coastal areas in Sweden. (WHO $=$ World Health Organization)

\begin{tabular}{|c|c|c|c|c|c|c|c|c|}
\hline \multirow[t]{2}{*}{ TEQ } & \multicolumn{2}{|c|}{ Sea of Bothnia } & \multicolumn{2}{|c|}{ Baltic Proper } & \multicolumn{2}{|c|}{ Baltic South } & \multicolumn{2}{|c|}{ West coast } \\
\hline & $\begin{array}{c}\text { Fisher- } \\
\text { men }\end{array}$ & Referents & $\begin{array}{c}\text { Fisher- } \\
\text { men }\end{array}$ & Referents & $\begin{array}{c}\text { Fisher- } \\
\text { men }\end{array}$ & Referents & $\begin{array}{c}\text { Fisher- } \\
\text { men }\end{array}$ & Referents \\
\hline $\begin{array}{l}\text { PCDD/PCDF } \\
\text { Non-ortho PCB } \\
\text { Mono- and di-ortho-PCB }\end{array}$ & $\begin{array}{l}154 \\
67 \\
83 \\
\end{array}$ & $\begin{array}{l}40 \\
28 \\
38\end{array}$ & $\begin{array}{l}80 \\
62 \\
69\end{array}$ & $\begin{array}{l}37 \\
35 \\
41\end{array}$ & $\begin{array}{l}131 \\
114 \\
112\end{array}$ & $\begin{array}{l}54 \\
47 \\
60\end{array}$ & $\begin{array}{l}42 \\
40 \\
57\end{array}$ & $\begin{array}{l}39 \\
30 \\
42\end{array}$ \\
\hline Total & 304 & 106 & 211 & 113 & 357 & 161 & 139 & 111 \\
\hline
\end{tabular}

lacking or inconclusive (38). However, no previous data indicate that the fat content of the fish is of any importance for the dietary load of selenium. Consequently no difference in plasma selenium levels was seen between east- and westcoast fishermen, in spite of the discrepancy in fish species consumed.

The fishermen, with a consumption of fish twice as high as the local referents, had methylmercury levels in blood that were twice as high as those of the referents. Out of the total mercury in blood, only a minor fraction was inorganic (10 and 14\% in fishermen and referents, respectively), and thus the main part was probably methylmercury. The present data support the earlier findings indicating that methylmercury intake through fish is a major source of mercury exposure in the Swedish population. The mercury concentrations were in accordance with those found in other studies of Swedes, by use of the same (or similar) analytical technique $(33,35,36,39$, and Schütz et al, unpublished report).

The mercury levels determined in our study were, however, far lower than recorded for Swedish "fish-eaters" during the 1960s and 1970s $(19,40)$. This is probably a result of dietary recommendations and decreasing methylmercury levels in fish, as a result of reductions in mercury pollution.

The measured urinary levels of methylamines agreed with the limited information on the concentrations of these amines in humans $(28,41,42)$. The higher levels of amines in the marine fish from the west coast, as compared with those of the brackish-water fish from the Baltic Sea (43), are the most probable explanation for the observed difference in amine excretion between the eastand westcoast fishermen.

The eastcoast fishermen had higher blood levels of PCDD/PCDF and PCB, expressed as the TEQ, than the westcoast fishermen, who in turn had blood levels of these substances of the same magnitude as the referents from both the east and west coast. The levels of the organochlorine compounds were thus related to the estimated exposure to these compounds from fatty fish consumption.
The levels of PCDD/PCDF in the pooled plasma samples from the eastcoast fishermen were systematically higher than those previously found among high consumers of fish from the Baltic Sea (13). However, the analyses have been performed at different laboratories. The laboratory used in the previous study (13) reanalyzed the pooled plasma samples from the Sea of Bothnia and the west coast in the present study. The level of PCDD/PCDF found, expressed as the TEQ, was very similar to that previously measured for high consumers of fatty fish from the Baltic Sea, and this level was about four times higher than that found in our westcoast sample.

For the non-ortho $\mathrm{PCB}$, the levels were in reasonable accordance with those found in another study on high consumers of fish from the Baltic Sea (11). Overall agreement was also found between the levels of the monoortho and other PCB in our pooled plasma samples and those previously reported (11), with the exception of the PCB congener IUPAC 153, which was lower than before.

The most essential findings in our study were that the dietary intake of fatty fish from the Baltic Sea was substantially higher among the eastcoast fishermen than among both the westcoast fishermen and referents from the general population and that this difference was reflected in corresponding differences in plasma levels of persistent organochlorine compounds.

It is thus justified to use the eastcoast fishermen as a study base for assessing cancer incidence and causespecific mortality in association with a high dietary intake of persistent organochlorine compounds (22).

\section{Acknowledgments}

This work was supported by grants from the Swedish Environmental Protection Agency, the Swedish Work Environment Fund, the Swedish Cancer Society, Gun- 
nar, Arvid and Elisabeth Nilsson's Fund for Research on Cancer, and the Medical Faculty, Lund University.

\section{References}

1. Kromhout D, Bosschieter EB, Lezenne Coulander C. The inverse relation between fish consumption and 20-year mortality from coronary heart disease. N Engl J Med 1985;312: $1205-9$

2. Cappon C, Crispin Smith J. Chemical form and distribution of mercury and selenium in eadible seafood. $J$ Anal Toxicol 1982;6:10-21

3. Bruce $\AA$. Selen — aktuella näringsfysiologiska och medicinska data [Selenium - nutritional and medical data]. Vår Föda 1985;37:272-81.

4. Salonen JT, Alfthan G, Huttunen JK, Puska P. Association between serum selenium and the risk of cancer. Am J Epidemiol 1984;120:342-9.

5. Salonen JT, Alfthan G, Huttunen JK, Pikkarainen J, Huttunen JK, Puska P. Association between cardiovascular death and myocardial infarction and serum selenium in a matched-pair longitudinal study. Lancet 1982;2:175 - 9 .

6. Beaglehole R, Jackson R, Watkinson J, Scragg R, Yee RL. Decreased blood selenium and risk of myocardial infarction. Int J Epidemiol 1990;19:918-22.

7. Suadicani P, Hein HO, Gyntelberg F. Serum selenium concentration and risk of ischemic heart disease in a prospective cohort study of 3000 males. Atherosclerosis 1992:96:33-42.

8. International Agency for Research on Cancer (IARC). Overall evaluations of carcinogenicity: an updating of IARC monographs, volumes 1-42. Lyon: IARC, 1987. IARC monographs, suppl 7.

9. Skene SA, Dewhurst IC, Greenberg M. Polychlorinated dibenzo-p-dioxins and polychlorinated dibenzofurans: the risks to human health. Hum Toxicol 1989;8:173-203.

10. Asplund L, Jansson B, de Wit C, Bergek S, Hjelt M, Rappe C, et al. Polychlorinated dibenzo-p-dioxins (PCDD) and dibenzofurans (PCDF) compared to other organohalogen pollutants in biological samples from Swedish ecosystems [extended abstract]. In: Hutzinger O, Fiedlertt, editors. Dioxin '90, 1990, Bayreuth, FRG: Eco-Informa Press, 1990:405-8.

11. Asplund L, Svensson B-G, Nilsson A, Eriksson U, Jansson B, Jensen $S$, et al. PCB, p,p'-DDT and p,p'-DDE, in human plasma related to fish consumption. Arch Environ Health. In 1994:49:477-86.

12. Rappe C, Bergqvist PA, Kjeller LO. Levels, trends and patterns of PCDDs and PCDFs in Scandinavian environmental samples. Chemosphere 1989;18:651-8.

13. Svensson B-G, Nilsson A, Hansson M, Rappe C, Åkesson B, Skerfving S. Exposure to dioxins and dibensofurans through the consumption of fish. N Engl J Med 1991;324:8-12.

14. Committee on Diet, Nutrition, and Cancer, National Research Council. Naturally occurring carcinogens. In: Diet, nutrition, and cancer. Washington DC: National Academic Press, 1982: 12:2-43.

15. Bartsch H, Montesano R. Relevance of nitrosamine to human cancer. Carcinogenesis 1984;5:1381-8.

16. World Health Organization (WHO), International programme on chemical safety. Methylmercury. Geneva: WHO, 1990. Environmental health criteria 101

17. Svensson B-G, Schütz A, Nilsson A, Åkesson I, Åkesson B, Skerfving $S$. Fish as a source of exposure to mercury and selenium. Sci Total Environ 1992;126:61—74.
18. National Swedish Environment Protection Agency. Metallerna och miljön: Miljön i Sverige - tillstånd och trender [Metals in the environment]. Solna: Naturvårdsverket, 1993. Rapport 4135.

19. Skerfving S. Methylmercury exposure, mercury levels in blood and hair, and health status in Swedes consuming contaminated fish. Toxicology 1974;2:3-23.

20. Boffetta P, Merler E, Vainio H. Carcinogenicity of mercury and mercury compounds. Scand J Work Environ Health 1993; 19:1-7.

21. Hagmar L, Lindén K, Nilsson A, Norrving, B, Åkesson B, Schütz A, et al. Cancer incidence and mortality among Swedish Baltic Sea fishermen. Scand J Work Environ Health 1992; $18: 217-24$.

22. Svensson B-G, Mikoczy Z, Strömberg U, Hagmar L. Mortality and cancer incidence among Swedish fishermen with a high dietary intake of persistent organochlorine compounds. Scand J Work Environ Health 1995;21:106-15.

23. Durrington PN, Ishola M, Hunt L, Arrol S, Bhatnagar D. Apolipoproteins(a), A1 and B and parental history in men with early onset ischaemic heart disease. Lancet 1988;1: 1070-3.

24. Einarsson Ö, Lindstedt G, Bergström T A. A computerised automatic apparatus for determination of mercury in biological samples. J Autom Chem 1984;6:74-9.

25. Skare I. Microdetermination of mercury in biological samples: III. automated determination of mercury in urine, fish and blood samples. Analyst 1972;97:148-55.

26. Brunmark P, Skarping G, Schütz A. Determination of methylmercury in human blood using capillary gas chromatography and selected-ion monitoring. J Chromatogr 1992;573:35-41.

27. LaLonde L, Jean Y, Roberts KD, Chapdelaine A, Bleau G. Fluorometry of selenium in serum or urine. Clin Chem 1982; 28:172-4.

28. Svensson B-G, Akesson B, Nilsson A, Paulsson K. Urinary excretion of methylamines in men with varying intake of fish from the Baltic Sea. J Toxicol Environ Health. 1994;41:41120.

29. Lustgarten J, Wenk R. Simple, rapid kinetic method for serum creatinine measurement. Clin Chem 1972;18:1419-22.

30. Yrjänheikki EJ. Levels of PCBs, PCDDs and PCDFs in human milk and blood: second round of quality control studies. Copenhagen: WHO, 1991. Environment and health in Europe, 37.

31. Ahlborg UG, Becking GC, Birnbaum LS, Brouwer A, Derks HJG M, Feeley M, et al. Toxic equivalency factors for dioxinlike PCBs. Chemosphere 1994;6:28.

32. Ahlborg U, Håkansson $\mathrm{H}$, Waern $\mathrm{F}$, Hanberg A. Nordisk dioxin risk bedömning. København: Nordiska Ministerrådet, 1988. Miljörapport, 7.

33. Svensson B-G, Björnham A, Schütz A, Lettevall U, Nilsson A, Skerfving S. Acidic deposition and human exposure to toxic metals. Sci Total Environ 1987;67:101-15.

34. Ohlsson K, Schütz A, Attewell R, Skerfving S. Selenium status in females with cervico-brachial complaints. Int Arch Occup Environ Health 1988;61:167—9.

35. Bensryd I, Rylander L, Högstedt B, Aprea P, Bratt I, Fåhraéus $C$, et al. Effect of acid precipitation on retention and excretion of elements in man. Sci Total Environ. 1994;145:81-102.

36. Åkesson I, Schütz A, Attewell R, Skerfving S, Glantz P-O. Status of mercury and selenium in dental personnel - impact of amalgam work and own fillings. Arch Environ Health 1991;46:102-9.

37. Thorngren M, Åkesson B. Effect of dietary fish on plasma 
selenium and its relation to haemostatic canges in healthy adults. Int J Vital Nutr Res 1987;57:429-35.

38. Mutanen M. Bioavailablity of selenium. Ann Clin Res 1986; $18: 48-54$

39. Erfurth EM, Schütz A, Nilsson A, Skerfving S. Normal pituitary hormone response to thyrotropin and gonadotropin releasing hormones in subjects exposed to elemental mercury vapour. Br J Ind Med 1990;47:639- 44.

40. Tejning S. De internationella och svenska födoämneshygieniska gränsvärdena för kvicksilver i belysning av kvicksilverhalter i fisk samt i blodkroppar, blodplasma och hår hos människa. [International and Swedish standards concerning the mercury contents in food stuffs in the light of the amount present in fish, in blood corpuscles, blood plasma and hair of man]. Nord Hyg Tidskr 1969;50:103-15.
41. Zeisel SH, DaCosta KA, La Mont, JT. Mono- di- and trimethylamine in human gastric fluid: potential substrates for nitrosodimethylamine formation. Carcinogenesis 1988;9:17981.

42. Lundh T, Åkesson B. Gas chromatographic determination of primary and secondary low-molecular-mass aliphatic amines in urine using derivatization with isobutyl chloroformate. J Chromatogr 1993;617:191-6.

43. Singer GM, Lijinsky W. Naturally occurring nitrosable compounds, I. secondary amines in foodstuffs. J Agric Food Chem $1976 ; 24: 550-3$

Received for publication: 25 March 1994 